\title{
Effects of SERCA and PMCA Inhibitors on the Survival of Rat Cochlear Hair Cells during Ischemia in vitro
}

\author{
N. AMARJARGAL ${ }^{1}$, B. MAZUREK ${ }^{1}$, H. HAUPT ${ }^{1}$, N. ANDREEVA ${ }^{2}$, J. FUCHS ${ }^{1}$, J. GROSS ${ }^{1}$ \\ ${ }^{1}$ Molecular Biological Research Laboratory, Department of Otorhinolaryngology, Charité - \\ University Medicine Berlin, Campus Charité Mitte, Berlin, Germany, ${ }^{2}$ Brain Research Institute, \\ Academy of Medical Sciences, Moscow, Russia
}

Received April 4, 2007

Accepted May 23, 2007

On-line July 26, 2007

\begin{abstract}
Summary
An important mechanism underlying cochlear hair cell (HC) susceptibility to hypoxia/ischemia is the influx of $\mathrm{Ca}^{2+}$. Two main ATP-dependent mechanisms contribute to maintaining low $\mathrm{Ca}^{2+}$ levels: uptake of $\mathrm{Ca}^{2+}$ into intracellular stores via smooth endoplasmic reticulum calcium ATPase (SERCA) and extrusion of $\mathrm{Ca}^{2+}$ via plasma membrane calcium ATPase (PMCA). The effects of the SERCA inhibitors thapsigargin $(10 \mathrm{nM}-10 \mu \mathrm{M})$ and cyclopiazonic acid (CPA; 10-50 $\mu \mathrm{M})$ and of the PMCA blockers eosin (1.5-10 $\mu \mathrm{M})$ and o-vanadate (1-5 mM) on inner and outer hair cells (IHCs/OHCs) were examined in normoxia and ischemia using an in vitro model of the newborn rat cochlea. Exposure of the cultures to ischemia resulted in a significant loss of HCs. Thapsigargin and CPA had no effect. Eosin decreased the numbers of IHCs and OHCs by up to $25 \%$ in normoxia and significantly aggravated the ischemia-induced damage to IHCs at 5 and $10 \mu \mathrm{M}$ and to OHCs at $10 \mu \mathrm{M}$. o-Vanadate had no effect on $\mathrm{IHC}$ and $\mathrm{OHC}$ counts in normoxia, but aggravated the ischemiainduced $\mathrm{HC}$ loss in a dose-dependent manner. The effects of eosin and o-vanadate indicate that PMCA has an important role to play in protecting the HCs from ischemic cell death.
\end{abstract}

\section{Key words}

Calcium • Organ of Corti $\bullet$ Ischemia $\bullet$ PMCA • Rat

\section{Corresponding author}

J. Gross, Molecular Biological Research Laboratory, Department of Otorhinolaryngology, Charité - University Medicine Berlin, Campus Charité Mitte, Charitéplatz 1, 10117 Berlin, Germany. Fax +49-30-450555 908. E-mail: johann.gross@charite.de

\section{Introduction}

Hypoxia/ischemia is an important pathogenetic factor contributing to inner ear diseases. Sudden hearing loss, noise induced hearing loss and presbyacusis are believed to be associated with hypoxia/ischemia (Riva et al. 2007).

In the auditory system, $\mathrm{Ca}^{2^{+}}$participates in regulating several activities of the cochlear sensory hair cells (HCs), including depolarization and repolarization, neurotransmitter release, adaptation and HC motility (Crawford et al. 1991, Lewis and Hudspeth 1983). These functions are provided by different $\mathrm{Ca}^{2+}$ concentrations in the fluids of the internal ear, the perilymph (PL) and the endolymph (Bosher and Warren 1978), which are presumably maintained by active processes (Furuta et al. 1998). Ischemia-induced neuronal cell death was shown to be largely determined by increases in the intracellular $\mathrm{Ca}^{2+}$ concentration (Wang et al. 2002). The increase of intracellular $\mathrm{Ca}^{2+}$ levels has several consequences: activation of $\mathrm{Ca}^{2+}$ regulated enzymes, mitochondrial $\mathrm{Ca}^{2+}$ overload, cytoskeletal disruption or activation of calpains (Lipton 1999, Missiaen et al. 2000). Excessive $\mathrm{Ca}^{2+}$ increase may lead to cell death via apoptosis or necrosis (Orrenius et al. 2003).

There are several processes which are involved in maintaining a low $\mathrm{Ca}^{2+}$ level within the cochlear HCs: regulated $\mathrm{Ca}^{2+}$ uptake, intracellular $\mathrm{Ca}^{2+}$ buffers (Slepecky and Ulfendahl 1993), intracellular compartmentalization (Tucker and Fettiplace 1995) and active extrusion (Ikeda et al. 1992). $\mathrm{Ca}^{2+}$ is continuously 
removed from the cells' cytoplasm via two ATPdependent pathways: plasma membrane $\mathrm{Ca}^{2+}$ ATPase (PMCA) and smooth endoplasmic reticulum $\mathrm{Ca}^{2+}$ ATPase (SERCA). The PMCA regulates the cytosolic $\mathrm{Ca}^{2+}$ concentration by extruding $\mathrm{Ca}^{2+}$ in a calmodulindependent manner (Carafoli 1997). Many studies have shown that PMCA is present in the HC bundles of the mammalian cochlea (Apicella et al. 1997, Crouch and Schulte 1995) where it is crucial for regulating the $\mathrm{Ca}^{2+}$ ion level during transduction (Dumont et al. 2001, Yamoah et al. 1998). Recently, immunohistochemical studies have demonstrated that PMCA is expressed not only in the $\mathrm{HC}$ bundles of both inner and outer hair cells (IHCs/OHCs), but also in their basolateral membranes (Dumont et al. 2001).

The SERCA-type intracellular $\mathrm{Ca}^{2+}$ pump transports $\mathrm{Ca}^{2+}$ ions from the cytoplasm to the intracellular $\mathrm{Ca}^{2+}$ stores. In the IHCs, the intracellular $\mathrm{Ca}^{2+}$ ions $\left(\left[\mathrm{Ca}^{2+}\right]_{\mathrm{i}}\right)$ can be taken up into intracellular stores and be released to modulate signal transduction. The SERCA seems to play a crucial role in compartmentalization of $\left[\mathrm{Ca}^{2+}\right]_{\mathrm{i}}$ signals (Kennedy 2002). In the HCs, the SERCA exerts modulating effects rather than displaying clearing activities (Evans et al. 2000, Kennedy 2002). In the OHCs, $\mathrm{Ca}^{2+}$ from intracellular stores contributes to augmentation of the acetylcholine (ACh)-evoked $\mathrm{Ca}^{2+}$ in the postsynaptic $\mathrm{HC}$ region by providing $\mathrm{Ca}^{2+}$ release in response to $\mathrm{Ca}^{2+}$ influx (Evans et al. 2000). Coupling between $\left[\mathrm{Ca}^{2+}\right]_{\mathrm{i}}$ stores and the $\mathrm{Ca}^{2+}$ permeability of the plasma membrane was reported (Mason et al. 1991). The action of $\mathrm{ACh}$ on the $\mathrm{OHC}$ current is fast and requires both extracellular and intracellular $\mathrm{Ca}^{2+}$ (Frolenkov et al. 2003). $\mathrm{Ca}^{2+}$ can also be extruded via $\mathrm{Na}^{+}-\mathrm{Ca}^{2+}$ exchange using the energy from the $\mathrm{Na}^{+}$gradient. This mechanism was found to be active in OHCs but with a low capacity (Ikeda et al. 1992). It was found to be inactive in IHCs (Kennedy 2002). The relative contribution of the $\mathrm{Ca}^{2+}$ clearance systems is not known for cochlear HCs.

To assess the contribution of $\mathrm{Ca}^{2+}$ uptake by SERCA and $\mathrm{Ca}^{2+}$ extrusion by PMCA to cochlear $\mathrm{HC}$ survival during ischemia, we examined the effect of the SERCA inhibitors thapsigargin and cyclopiazonic acid (CPA) and of the PMCA blockers eosin and o-vanadate at different concentrations on IHC and OHC loss in normoxia and ischemia using an in vitro model of the newborn rat cochlea (Gatto et al. 1995, Mazurek et al. 2003, Thastrup et al. 1990).

\section{Methods}

For this study, an in vitro model of the organ of Corti from 3-5 day old Wistar rats $(n=109)$ was used (Cheng et al. 1999, Lowenheim et al. 1999). The pups were surface-sterilized with $70 \%$ ethanol and decapitated. The left and right temporal bones were dissected in buffered saline glucose (BSG) plus ciprobay under sterile conditions. The otic capsule was removed and the membranous cochleae were prepared. Then, the modiolus and stria vascularis were removed from the organ of Corti and the specimens were divided into their apical, middle and basal parts.

The fragments were cultured in four-well microtiter plates $(500 \mu \mathrm{l} /$ well $)$ in Dulbecco's modified Eagle's medium/F12 nutrient mixtures (DMEM/F12, Gibco, Karlsruhe, Germany) (1:1) medium with $10 \%$ fetal calf serum (FCS), $10 \mathrm{mM}$ HEPES, $5 \mathrm{mM}$ L-glutamine, $50 \mathrm{U} / \mathrm{ml}$ ciprobay, $100 \mu \mathrm{g} / \mathrm{ml}$ transferrin, $60 \mu \mathrm{g} / \mathrm{ml}$ putrescine, $25 \mu \mathrm{g} / \mathrm{ml}$ insulin, $0.6 \%$ glucose. The cultures were placed in an incubator at $37^{\circ} \mathrm{C}$ and were grown for overnight. For experimental incubation, an artificial $\mathrm{PL}$ like electrolyte solution (in $\mathrm{mM}$ : $125 \mathrm{NaCl}, 5 \mathrm{KCl}, 2 \mathrm{CaCl}_{2}, 1.2 \mathrm{MgCl}_{2}, 1.99$ EGTA, 20 HEPES, $24 \mathrm{NaHCO}_{3}$ and 10 glucose) (Bobbin et al. 2003, Wanaverbecq et al. 2003) was used.

Ischemia was mimicked by incubating the fragments in artificial PL without glucose $(500 \mu \mathrm{l} /$ well $)$ in a Billups-Rothenberg chamber for $4 \mathrm{~h}$. The chamber containing the plates was perfused with a calibrated gas mixture of $5 \% \mathrm{CO}_{2}$ and $95 \% \mathrm{~N}_{2}$ (AGA Gas $\mathrm{GmbH}$, Bottrop, Germany). After 15 min perfusion at a flow rate of $20 \mathrm{l} / \mathrm{min}$, the $\mathrm{pO}_{2}$ in artificial PL was $10-20 \mathrm{~mm} \mathrm{Hg}$, and remained at the same level during incubation. Controls were incubated in the same incubator for $4 \mathrm{~h}$ in artificial PL.

To study the effect of SERCA and PMCA inhibitors on the $\mathrm{HCs}$, the cultures were grouped as follows: 1) controls, i.e., incubation in artificial PL in normoxia $(n=19) ; 2)$ ischemia, i.e., exposure to hypoxia in artificial PL without glucose $(\mathrm{n}=23) ; 3)$ incubation in artificial PL with increasing concentrations of thapsigargin $(10,100 \mathrm{nM}$ and $1,10 \mu \mathrm{M})$ in normoxia $(\mathrm{n}=21)$ and ischemia $(\mathrm{n}=22)$; 4) incubation in artificial PL with 10 and $50 \mu \mathrm{M} \mathrm{CPA}$ in normoxia $(\mathrm{n}=14)$ and ischemia $(\mathrm{n}=18) ; 5)$ incubation in artificial PL with increasing concentrations of eosin $(1.5,5,10 \mu \mathrm{M})$ in normoxia $(n=33)$ and ischemia $(n=41) ; 6)$ incubation in artificial PL with 1 and $5 \mathrm{mM}$ o-vanadate in normoxia 

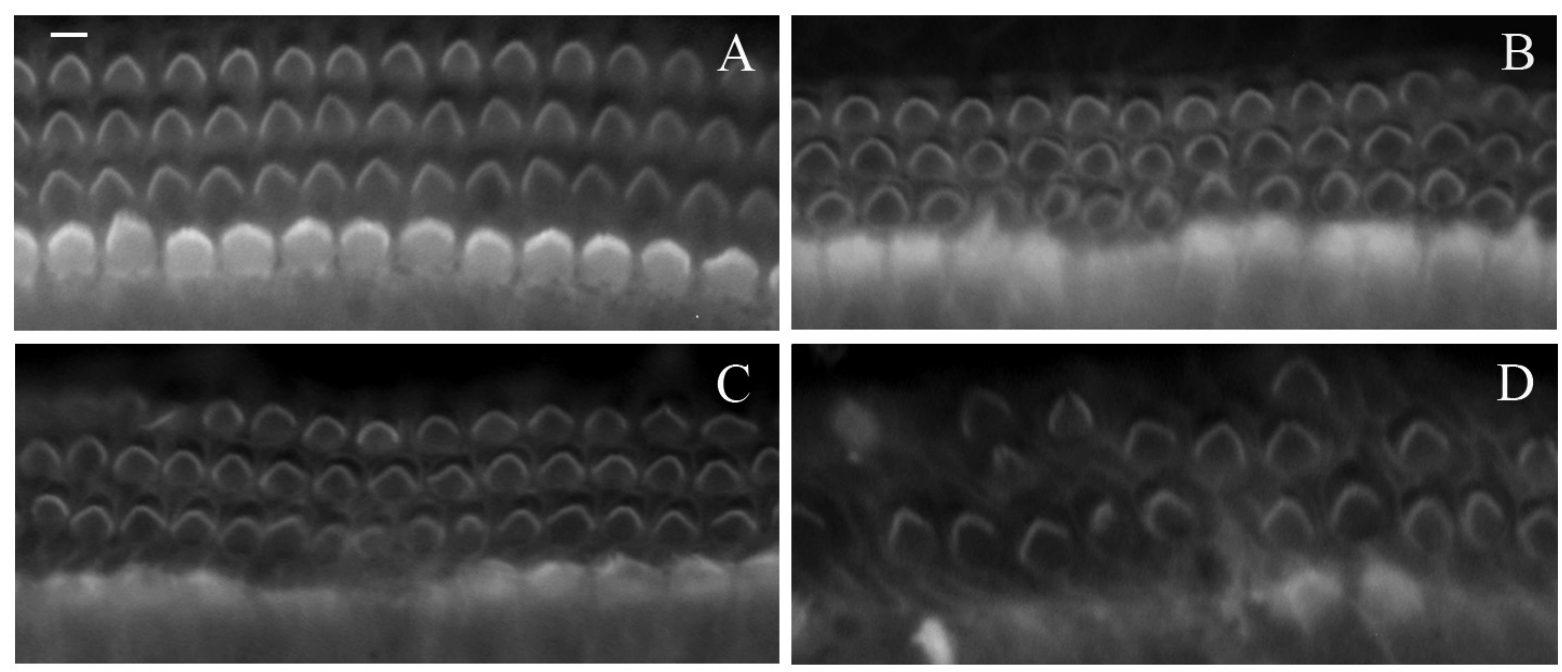

Fig. 1. Representative images of phalloidin-labeled whole mounts of the rats' organ of Corti under different conditions showing the basal cochlear parts. A - normoxia; B - normoxia and $10 \mu \mathrm{M}$ eosin; C - ischemia; D - ischemia and eosin (10 $\mu \mathrm{M})$. Under normoxic conditions, one row of intact inner hair cells (IHCs) and three rows of intact outer hair cells are to be seen. Eosin and ischemia resulted in irregular loss of hair cells, especially of IHCs. Bar $10 \mu \mathrm{m}$.

$(\mathrm{n}=19)$ and ischemia $(\mathrm{n}=15)$. After incubation, the cultures were returned to their own culture conditioned medium and were incubated for overnight. Thapsigargin and CPA (Sigma) were dissolved as $100 \mathrm{mM}$ and $10 \mathrm{mM}$, respectively, stock solutions in dimethylsulfoxide and were stored frozen. Eosin and o-vanadate (Sigma) were stored as aqueous stock solutions $(10 \mathrm{mM}$ and $200 \mathrm{mM}$, respectively). Aliquots were diluted with artificial PL on the day of use.

$24 \mathrm{~h}$ after ischemia, the cultures were rinsed with phosphate buffered saline (PBS) and fixed at room temperature in $3.5 \%$ paraformaldehyde/0.1 M PBS for $35 \mathrm{~min}$. Then, the fragments were washed two times with PBS and permeabilized with $0.2 \%$ Triton X-100 in PBS for $30 \mathrm{~min}$. For staining, the fragments were incubated in phalloidin TRIC (tetramethyl rhodamine isothiocyanate, Sigma) at room temperature for $30 \mathrm{~min}$. Phalloidin is a specific marker for cellular F-actin and stains stereocilia and the cuticular plate. The HCs were identified on a Leica DMIL fluorescence microscope. The number of HCs was counted over a distance of 3 times $100 \mu \mathrm{m}$ in the one IHC row and the three $\mathrm{OHC}$ rows at a magnification of $\times 400$. Cells were considered missing when there was a gap in the normal geometric array and no stereocilia or cuticular plate were to be seen. Partially damaged hair cells were considered as missing, when more than $50 \%$ of the stereocilia and of the cuticular plate were not seen.

The means \pm S.E.M. were calculated for all parameters measured. One-way or two-way analysis of variance (ANOVA) was used to compare the HC damage between the experimental groups, the cochlear parts and the IHCs and OHCs. Additionally, Bonferroni's post hoc test was used for specifically testing the means. $\mathrm{P}<0.05$ value was the criterion for significance. All statistical tests and graphs were made using Statistica 7.0 (StatSoft).

All studies were performed in accordance with the German Prevention of Cruelty to Animals Act and permission was obtained from the Berlin Senate Office for Health (T0234/00).

\section{Results}

Number of IHCs and OHCs in control and ischemia exposed cultures

Figure 1 shows representative images of HCs of the organ of Corti under different conditions. The normoxic controls showed a normal regular architecture in the IHC row and in the three $\mathrm{OHC}$ rows for up to $48 \mathrm{~h}$ of cultivation (Fig. 1A). The numbers of IHCs and OHCs amounted to $9.5 \pm 0.1$ and $12.2 \pm 0.1 / 100 \mu \mathrm{m}$, respectively, in each row (Fig. 2). In explants exposed to ischemia or eosin, irregular loss of HCs was observed (Figs 1B-1D). Exposure of the cultures to ischemia for $4 \mathrm{~h}$ resulted in a significant loss of IHCs and OHCs in the whole organ of Corti counted $24 \mathrm{~h}$ after ischemia $(\mathrm{P}=0.0001$ vs. controls). The loss of IHCs amounted to $35-51 \%$ and that of OHCs to $15-25 \%$ in the apical, middle and basal parts, with the apical parts being less affected in both HC types $(\mathrm{P}<0.01$ vs. middle or basal parts; Fig. 2$)$. 


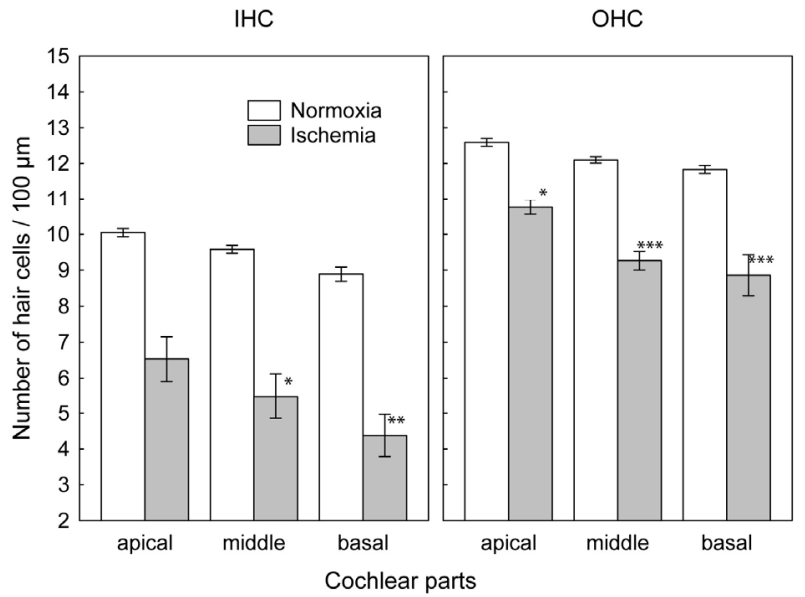

Fig. 2. Mean number ( \pm S.E.M.) of inner and outer hair cells $(\mathrm{IHC} / \mathrm{OHC}) / 100 \mu \mathrm{m}$ per row counted in the apical, middle and basal parts of the organ of Corti in normoxia $(n=19)$ and ischemia $(\mathrm{n}=23)$ groups $(* / * * / * * * \quad \mathrm{P}<0.05 / 0.01 / 0.001$ vs. normoxia).

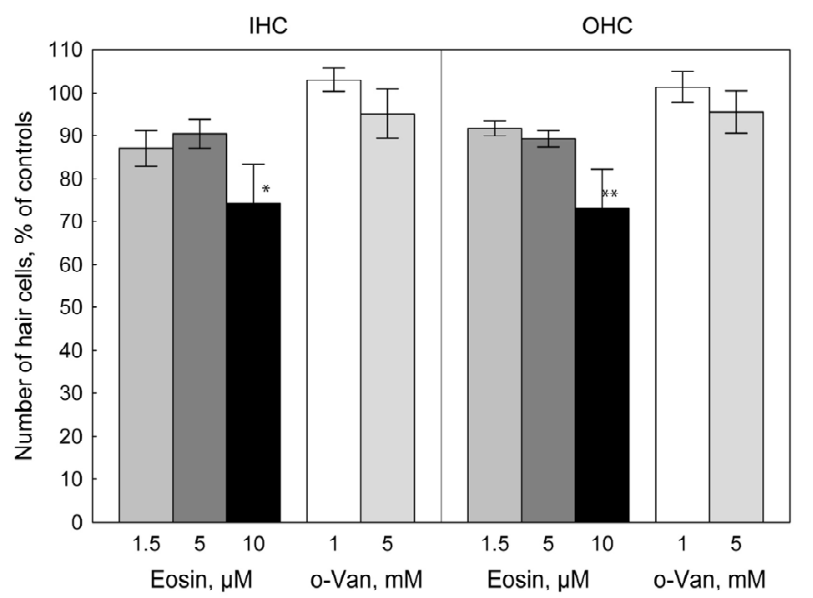

Fig. 3. Number of inner and outer hair cells (IHC/OHC; \% of controls; mean \pm S.E.M.) counted in the normoxia groups with $1.5 \mu \mathrm{M}(\mathrm{n}=15), 5 \mu \mathrm{M}$ and $10 \mu \mathrm{M}(\mathrm{n}=9$ each) eosin or $1 \mathrm{mM}$ $(n=6)$ and $5 \mathrm{mM}(\mathrm{n}=5)$ o-vanadate $(* / * * P<0.001 / 0.0001$ vs. controls).

\section{Effects of SERCA inhibitors}

The SERCA inhibitors thapsigargin (10 nM$10 \mu \mathrm{M})$ and CPA $(10$ and $50 \mu \mathrm{M})$, which were tested in this study, had no effect on HC survival in neither the normoxic nor the ischemia-exposed cultures, irrespective of the concentrations used (data not shown).

\section{Effects of PMCA blockers}

The PMCA blockers eosin $(1.5-10 \mu \mathrm{M})$ and o-vanadate (1 and $5 \mathrm{mM}$ ) differed in their effects on the $\mathrm{HCs}$ in normoxia (Fig. 3). Eosin decreased the $\mathrm{HC}$ numbers in a dose-dependent manner. The highest eosininduced damage was found to occur at a concentration of $10 \mu \mathrm{M}$ and amounted to about $25 \%$ in both HC types as

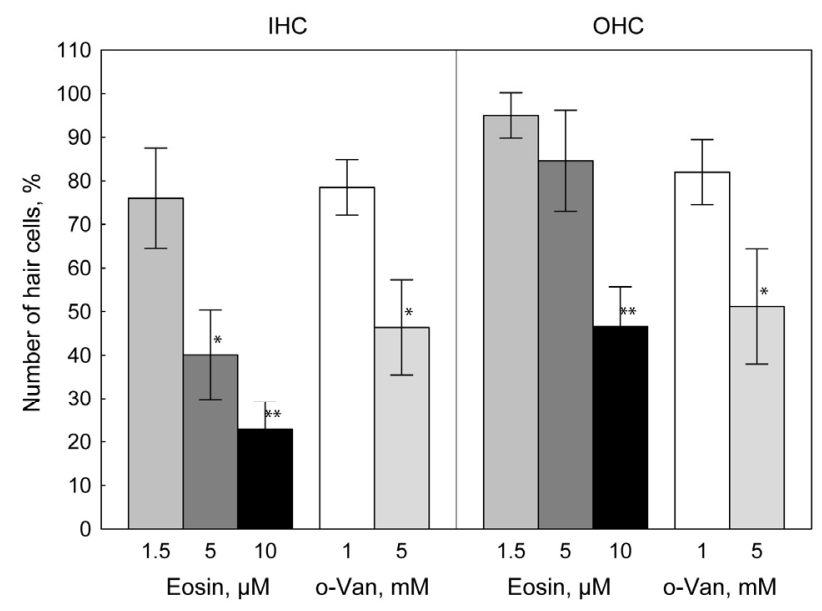

Fig. 4. Number of inner and outer hair cells ( $\mathrm{IHC} / \mathrm{OHC} ; \%$ of ischemia without drugs; mean \pm S.E.M.) determined in the whole organ of Corti in the ischemia groups with $1.5 \mu \mathrm{M}(n=20), 5 \mu \mathrm{M}$ $(n=11)$ and $10 \mu \mathrm{M}(n=10)$ eosin or $1 \mathrm{mM}(n=7)$ and $5 \mathrm{mM}$ $(\mathrm{n}=8) \quad 0$-vanadate $(* / * * \quad \mathrm{P}<0.01 / 0.001$ vs. ischemia without drugs).

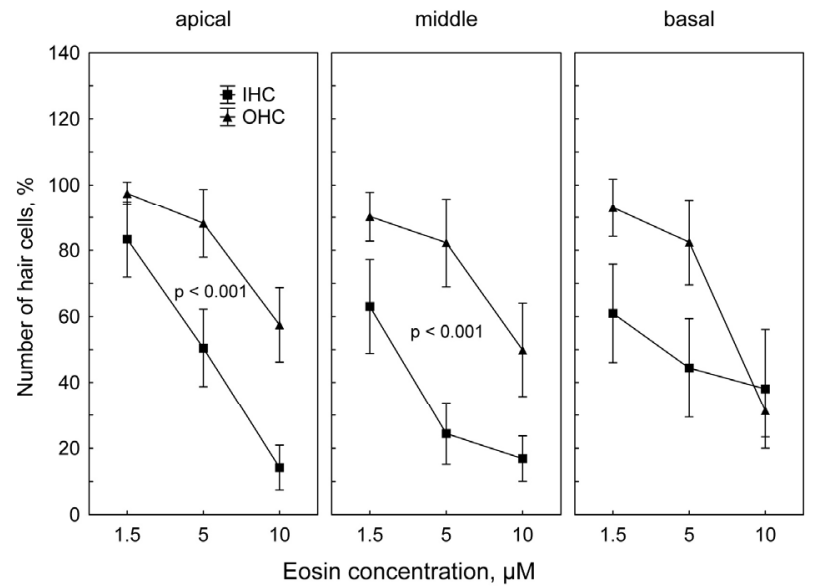

Fig. 5. Number of inner and outer hair cells (IHC/OHC; \% of ischemia without eosin; mean \pm S.E.M.) determined in the apical, middle and basal parts of the organ of Corti in the ischemia groups with $1.5 \mu \mathrm{M}(\mathrm{n}=20), 5 \mu \mathrm{M}(\mathrm{n}=11)$ and $10 \mu \mathrm{M}(\mathrm{n}=10)$ eosin.

compared to the controls. In contrast, o-vanadate had no effect on the IHC or OHC counts.

Both eosin and o-vanadate aggravated the ischemia-induced $\mathrm{HC}$ loss in a dose-dependent manner (Fig. 4). At eosin concentrations of $1.5 \mu \mathrm{M}$, no significant effect on either the IHCs or the OHCs was observed. High concentrations $(5 \mu \mathrm{M})$ of eosin caused $60 \%$ of the IHCs to be damaged as compared to ischemia, but they did not affect the OHCs. At a concentration of $10 \mu \mathrm{M}$, the eosin-induced damage amounted to about $80 \%$ in the IHCs and $50 \%$ in the OHCs as determined in the whole organ of Corti. ovanadate concentrations of $1 \mathrm{mM}$ had no additional 


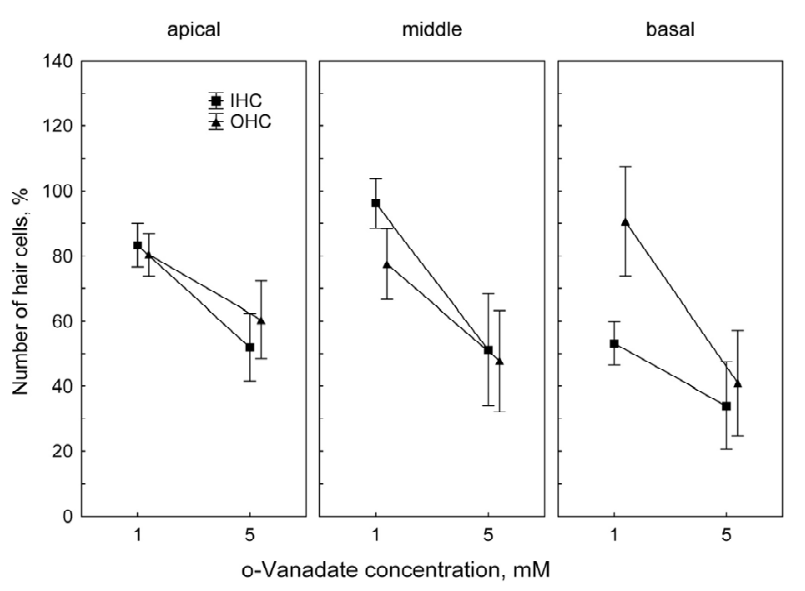

Fig. 6. Number of inner and outer hair cells (IHC/OHC; \% of ischemia without o-vanadate; mean \pm S.E.M.) determined in the apical, middle and basal parts of the organ of Corti in the ischemia groups with $1 \mathrm{mM}(\mathrm{n}=7)$ and $5 \mathrm{mM}(\mathrm{n}=8)$ ovanadate.

damaging effect on the IHCs or OHCs. However, high concentrations $(5 \mathrm{mM})$ induced an additional IHC loss by $45 \%$ and an OHC loss by about $50 \%$.

Effects of PMCA blockers on the apical, middle and basal regions of the organ of Corti in ischemia

When the two drugs were analyzed for their separate effects on the IHCs and OHCs in the apical, medial and basal regions, the IHCs' higher vulnerability to eosin in ischemia became obvious in the apical and middle parts (Fig. 5). In contrast, o-vanadate damaged both IHCs and OHCs to similar degrees (Fig. 6). The dose-dependence was similar for the apical, middle and basal regions.

\section{Discussion}

The major finding of the present study is that the PMCA blocker eosin induces a dose-dependent HC loss during normoxia and aggravates the ischemia-induced HC damage. The PMCA blocker o-vanadate has no effect on $\mathrm{HC}$ survival in normoxia, but enhances ischemiainduced HC loss. In contrast, the SERCA inhibitors thapsigargin and CPA do not affect $\mathrm{HC}$ survival in normoxia and ischemia. These data indicate that PMCA is a key enzyme involved in protecting hair cells from ischemia-induced loss.

\section{Role of calcium in ischemia-induced cell death}

The primary mechanism thought to be involved in ischemia-induced neuronal death is the massive increase in intracellular $\mathrm{Ca}^{2+}$ (Lipton 1999). In general, cytosolic $\mathrm{Ca}^{2+}$ may increase as a result of a net influx of $\mathrm{Ca}^{2+}$ across the plasma membrane or due to the release of $\mathrm{Ca}^{2+}$ from intracellular stores. Specific pathways of ischemia-induced influx of $\mathrm{Ca}^{2+}$ into the $\mathrm{HCs}$ are not known. It is assumed that the voltage-gated $\mathrm{Ca}^{2+}$ channel and NMDA (N-methyl-D-aspartate) receptor-activated $\mathrm{Ca}^{2+}$ channels are the main pathways of excessive $\mathrm{Ca}^{2+}$ influx, which may lead to HC death (Pujol et al. 1990). The roles of SERCA and PMCA in maintaining $\mathrm{Ca}^{2+}$ homeostasis following ischemia are presently unknown. In SH-SY5Y neuronal cells, it was shown that in ischemia, endoplasmatic reticulum (ER) $\mathrm{Ca}^{2+}$ is released via ryanodine receptor channels, thus contributing to the subsequent cell death (Wang et al. 2002). The release of ER $\mathrm{Ca}^{2+}$ has two separate consequences: an increase in cytosolic $\mathrm{Ca}^{2+}$ levels and a depletion of ER $\mathrm{Ca}^{2+}$, which will disrupt processes like protein folding and processing, i.e. functional activities important for cell viability.

The involvement of PMCAs in ischemic cell damage has been shown by Lehotsky et al. (1999). Transient forebrain ischemia $(10 \mathrm{~min})$ and reperfusion was shown to decrease the PMCA immuno-signal. The decrease was ascribed to the loss of the PMCA1 signal. This group also investigated the possible effects of ischemia and ischemia-reperfusion injury on $\mathrm{ER} \mathrm{Ca}^{2+}$ transport (Racay et al. 2000). No significant changes of the microsomal $\mathrm{Ca}^{2+}$ transport and of the $\mathrm{Ca}^{2+}$ ATPase activity were detected during and after ischemia.

\section{Effects of SERCA inhibitors on hair cell survival}

Our data show that in the in vitro organ of Corti culture, thapsigargin and CPA affect HC survival neither in normoxic nor in ischemic conditions indicating that SERCA has no important role in ensuring a certain $\mathrm{HC}$ survival rate. This observation is in line with the general functions of the ER (Verkhratsky 2004). It serves as a dynamic $\mathrm{Ca}^{2+}$ pool and has important signaling functions in neuronal cells. However, chronic changes in the $\mathrm{Ca}^{2+}$ homeostasis are involved in neurodegeneration and neuronal cell death. For example, Bobbin et al. (2003) observed in an in vivo guinea pig model that chronic application of thapsigargin $(10 \mu \mathrm{M}, 2$ weeks $)$ generated OHC loss, while IHCs were occasionally absent. This discrepancy as regards our results may be attributed mainly to the duration of thapsigargin exposure. It is also possible that the influence of SERCA on $\left[\mathrm{Ca}^{2+}\right]_{\mathrm{i}}$ may be different in different cell types (Yao et al. 1999). Our findings to the extent that SERCA inhibitors are not 
associated with $\mathrm{HC}$ death is in agreement with the observation of Martinez-Sanchez et al. (2004) who found this cell death to be similar in the presence and absence of CPA following oxygen glucose deprivation in organotypic hippocampal slice cultures.

\section{Effects of PMCA inhibitors on hair cell survival in normoxia and ischemia}

The clearly aggravating effect of the two PMCA inhibitors eosin and o-vanadate on $\mathrm{HC}$ death supports the assumption that PMCA is a key enzyme for the extrusion of excessive intracellular $\mathrm{Ca}^{2+}$ in the HCs (Yamoah et al. 1998). The PMCA inhibition is associated with an increase in the $\left[\mathrm{Ca}^{2+}\right]_{i}$ in resting cells as shown in neurons from the rat superior cervical ganglion (Wanaverbecq et al. 2003). The increase in $\left[\mathrm{Ca}^{2+}\right]_{\mathrm{i}}$ caused by eosin is most probably the reason for $\mathrm{HC}$ loss even in normoxic cultures. Unlike eosin, o-vanadate has no effect on $\mathrm{HC}$ survival in normoxic conditions. This difference may be associated with specific effects of o-vanadate in addition to PMCA inhibition. For example, sodium o-vanadate is a protein tyrosine phosphatase inhibitor and blocks delayed neuronal death in the CA1 region following ischemic insult (Fukunaga and Kawano 2003).

Our data show that the ischemia-induced HC loss is aggravated by PMCA blockers in an additive or synergistic manner. This led us to the conclusion that PMCA blockers and ischemia act by different mechanisms. This assumption is supported by the finding that caspases cleave and inactivate the PMCA pump in neurons and non-neuronal cells undergoing apoptosis (Schwab et al. 2002). The effects of PMCA inhibitors on hair cell survival observed in this paper are in agreement with findings that PMCAs are critical to PC12 cell survival (Garcia and Strehler 1999). Utilizing the model of the $\mathrm{Ca}^{2+}$ ionophore $\mathrm{A} 23187$ to induce $\mathrm{Ca}^{2+}$-mediated cell death, PMCA depleted PC12 cells expressing about $35 \%$ of the PMCA 4 in control cells, were found to be considerably more vulnerable to $\mathrm{Ca}^{2+}$-mediated cell death than control cells.

\section{Differential response of $\mathrm{IHCs}$ and $\mathrm{OHCs}$}

The IHCs' higher vulnerability to ischemia over that of the OHCs as found in the present study is in agreement with our previous observations (Mazurek et al. 2003). Several factors could contribute to the higher vulnerability of IHCs compared to OHCs (Mazurek et al. 2003): 1) ischemia-induced excitotoxicity could participate specifically to the preferred IHC cell death, because glutamate receptors play an important role in signal transduction between IHC and type 1 spiral ganglion (Pujol et al. 1990), 2) IHCs seem to produce less glycogen than OHCs, an important substrate under ischemic conditions (Hilding et al. 1977), 3) IHCs contain less mitochondria than OHCs, which may regulate the probability of survival after metabolic challenges of HC integrity (Hyde and Rubel 1995), and 4) the distribution and function of PMCA isoforms offer an additional explanation for the high IHC vulnerability to ischemia. The main plasma membrane $\mathrm{Ca}^{2+}$ ATPases of mammalian sensory HCs are the isoforms PMCA1 and PMCA2. PMCA1 is located in the HCs' basolateral membrane, whereas PMCA2 is localized exclusively at the apical plasma membrane of the stereocilia of OHCs and IHCs (Grati et al. 2006). IHC stereocilia had much less reactivity than those of OHCs. Using a monoclonal antibody to a large cytoplasmic loop of PMCA, a higher reactivity appeared in the cytoplasm of OHCs compared to IHCs (Apicella et al. 1997). In the cochlea of 3-5 day old rats, IHCs expressed PMCA1 at moderate levels, and OHCs expressed PMCA2 at high levels (Furuta et al. 1998). Assuming that ischemia or eosin and o-vanadate inhibit all isoforms to a similar degree, the differential PMCA activity could explain the higher vulnerability of IHCs in the present model.

Another explanation for the differing degrees of IHC and OHC vulnerability to eosin could be their different patterns of $\left[\mathrm{Ca}^{2+}{ }_{\mathrm{i}}\right]$ regulation (Kennedy 2002). IHCs pump $\mathrm{Ca}^{2+}$ out of the cell on an ATP-dependent PMCA, whereas OHCs additionally use the $\mathrm{Na}^{+}-\mathrm{Ca}^{2+}$ exchange driven by the $\mathrm{Na}^{+}$gradient.

In conclusion, PMCA appears to play a pivotal role in cytoplasmic $\mathrm{Ca}^{2+}$ extrusion from the $\mathrm{HCs}$ and contributes substantially to the survival of HCs under normoxic and ischemic conditions. In contrast, the $\mathrm{Ca}^{2+}$ uptake into the internal stores via SERCA appears to have no or little influence on HC survival.

\section{Conflict of Interest}

There is no conflict of interest.

\section{Acknowledgements}

This work was supported by a grant from the Humboldt University (Gr. 2003-415). Sadly, PhD Dr. Nadeshda Andreeva, a close friend of us and an outstanding scientist died after the completion of this paper. 


\section{References}

APICELLA S, CHEN S, BING R, PENNISTON JT, LLINAS R, HILLMAN DE: Plasmalemmal ATPase calcium pump localizes to inner and outer hair bundles. Neuroscience 79: 1145-1151, 1997.

BOBBIN RP, PARKER M, WALL L: Thapsigargin suppresses cochlear potentials and DPOAEs and is toxic to hair cells. Hear Res 184: 51-60, 2003.

BOSHER SK, WARREN RL: Very low calcium content of cochlear endolymph, an extracellular fluid. Nature 273: 377-378, 1978.

CARAFOLI E: Plasma membrane calcium pump: structure, function and relationships. Basic Res Cardiol 92 (Suppl 1): 59-61, 1997.

CHENG AG, HUANG T, STRACHER A, KIM A, LIU W, MALGRANGE B, LEFEBVRE PP, SCHULMAN A,VAN DE WATER TR: Calpain inhibitors protect auditory sensory cells from hypoxia and neurotrophinwithdrawal induced apoptosis. Brain Res 850: 234-243, 1999.

CRAWFORD AC, EVANS MG, FETTIPLACE R: The actions of calcium on the mechano-electrical transducer current of turtle hair cells. J Physiol Lond 434: 369-398, 1991.

CROUCH JJ, SCHULTE BA: Expression of plasma membrane Ca-ATPase in the adult and developing gerbil cochlea. Hear Res 92: 112-119, 1995.

DUMONT RA, LINS U, FILOTEO AG, PENNISTON JT, KACHAR B, GILLESPIE PG: Plasma membrane $\mathrm{Ca}^{2+}$ ATPase isoform 2a is the PMCA of hair bundles. $J$ Neurosci 21: 5066-5078, 2001.

EVANS MG, LAGOSTENA L, DARBON P, MAMMANO F: Cholinergic control of membrane conductance and intracellular free $\mathrm{Ca}^{2+}$ in outer hair cells of the guinea pig cochlea. Cell Calcium 28: 195-203, 2000.

FROLENKOV GI, MAMMANO F, KACHAR B: Regulation of outer hair cell cytoskeletal stiffness by intracellular $\mathrm{Ca}^{2+}$ : underlying mechanism and implications for cochlear mechanics. Cell Calcium 33: 185-195, 2003.

FUKUNAGA K, KAWANO T: Akt is a molecular target for signal transduction therapy in brain ischemic insult. J Pharmacol Sci 92: 317-327, 2003.

FURUTA H, LUO L, HEPLER K, RYAN AF: Evidence for differential regulation of calcium by outer versus inner hair cells: plasma membrane Ca-ATPase gene expression. Hear Res 123: 10-26, 1998.

GARCIA ML, STREHLER EE: Plasma membrane calcium ATPases as critical regulators of calcium homeostasis during neuronal cell function. Front Biosci 4: D869-D882, 1999.

GATTO C, HALE CC, XU W, MILANICK MA: Eosin, a potent inhibitor of the plasma membrane Ca pump, does not inhibit the cardiac Na-Ca exchanger. Biochemistry 34: 965-972, 1995.

GRATI M, AGGARWAL N, STREHLER EE, WENTHOLD RJ: Molecular determinants for differential membrane trafficking of PMCA1 and PMCA2 in mammalian hair cells. J Cell Sci 119: 2995-3007, 2006.

HILDING DA, BAHIA I, GINZBERG RD: Glycogen in the cochlea during development. Acta Otolaryngol 84: 12-23, 1977.

HYDE GE, RUBEL EW: Mitochondrial role in hair cell survival after injury. Otolaryngol Head Neck Surg 113: 530540, 1995.

IKEDA K, SAITO Y, NISHIYAMA A, TAKASAKA T: $\mathrm{Na}^{+}-\mathrm{Ca}^{2+}$ exchange in the isolated cochlear outer hair cells of the guinea-pig studied by fluorescence image microscopy. Pflugers Arch 420: 493-499, 1992.

KENNEDY HJ: Intracellular calcium regulation in inner hair cells from neonatal mice. Cell Calcium 31: 127-136, 2002.

LEHOTSKY J, KAPLAN P, RACAY P, MEZESOVA V, RAEYMAEKERS L: Distribution of plasma membrane $\mathrm{Ca}^{2+}$ pump (PMCA) isoforms in the gerbil brain: effect of ischemia-reperfusion injury. Neurochem Int 35: 221-227, 1999.

LEWIS RS, HUDSPETH AJ: Voltage- and ion-dependent conductances in solitary vertebrate hair cells. Nature 304: 538-541, 1983.

LIPTON P: Ischemic cell death in brain neurons. Physiol Rev 79: 1431-1568, 1999.

LOWENHEIM H, KIL J, GULTIG K, ZENNER HP: Determination of hair cell degeneration and hair cell death in neomycin treated cultures of the neonatal rat cochlea. Hear Res 128: 16-26, 1999. 
MARTINEZ-SANCHEZ M, STRIGGOW F, SCHRODER UH, KAHLERT S, REYMANN KG, REISER G: $\mathrm{Na}^{+}$and $\mathrm{Ca}^{2+}$ homeostasis pathways, cell death and protection after oxygen-glucose-deprivation in organotypic hippocampal slice cultures. Neuroscience 128: 729-740, 2004.

MASON MJ, GARCIA-RODRIGUEZ C, GRINSTEIN S: Coupling between intracellular $\mathrm{Ca}^{2+}$ stores and the $\mathrm{Ca}^{2+}$ permeability of the plasma membrane. Comparison of the effects of thapsigargin, 2,5-di-(tert-butyl)-1,4hydroquinone, and cyclopiazonic acid in rat thymic lymphocytes. J Biol Chem 266: 20856-20862, 1991.

MAZUREK B, WINTER E, FUCHS J, HAUPT H, GROSS J: Susceptibility of the hair cells of the newborn rat cochlea to hypoxia and ischemia. Hear Res 182: 2-8, 2003.

MISSIAEN L, ROBBERECHT W, VAN DEN BL, CALLEWAERT G, PARYS JB, WUYTACK F, RAEYMAEKERS L, NILIUS B, EGGERMONT J, DE SMEDT H: Abnormal intracellular $\mathrm{Ca}^{2+}$ homeostasis and disease. Cell Calcium 28: 1-21, 2000.

ORRENIUS S, ZHIVOTOVSKY B, NICOTERA P: Regulation of cell death: the calcium-apoptosis link. Nat Rev Mol Cell Biol 4: 552-565, 2003.

PUJOL R, REBILLARD G, PUEL JL, LENOIR M, EYBALIN M, RECASENS M: Glutamate neurotoxicity in the cochlea: a possible consequence of ischaemic or anoxic conditions occurring in ageing. Acta Otolaryngol Suppl 476: 32-36, 1990.

RACAY P, KAPLAN P, LEHOTSKY J: Ischemia-induced inhibition of active calcium transport into gerbil brain microsomes: effect of anesthetics and models of ischemia. Neurochem Res 25: 285-292, 2000.

RIVA C, DONADIEU E, MAGNAN J, LAVIEILLE JP: Age-related hearing loss in CD/1 mice is associated to ROS formation and HIF target proteins up-regulation in the cochlea. Exp Gerontol 42: 327-336, 2007.

SCHWAB BL, GUERINI D, DIDSZUN C, BANO D, FERRANDO-MAY E, FAVA E, TAM J, XU D, XANTHOUDAKIS S, NICHOLSON DW, CARAFOLI E, NICOTERA P: Cleavage of plasma membrane calcium pumps by caspases: a link between apoptosis and necrosis. Cell Death Differ 9: 818-831, 2002.

SLEPECKY NB, ULFENDAHL M: Evidence for calcium-binding proteins and calcium-dependent regulatory proteins in sensory cells of the organ of Corti. Hear Res 70: 73-84, 1993.

THASTRUP O, CULLEN PJ, DROBAK BK, HANLEY MR, DAWSON AP: Thapsigargin, a tumor promoter, discharges intracellular $\mathrm{Ca}^{2+}$ stores by specific inhibition of the endoplasmic reticulum $\mathrm{Ca}^{2+}$-ATPase. Proc Natl Acad Sci USA 87: 2466-2470, 1990.

TUCKER T, FETTIPLACE R: Confocal imaging of calcium microdomains and calcium extrusion in turtle hair cells. Neuron 15: 1323-1335, 1995.

VERKHRATSKY A: Endoplasmic reticulum calcium signaling in nerve cells. Biol Res 37: 693-699, 2004.

WANAVERBECQ N, MARSH SJ, AL QATARI M, BROWN DA: The plasma membrane calcium-ATPase as a major mechanism for intracellular calcium regulation in neurones from the rat superior cervical ganglion. $J$ Physiol Lond 550: 83-101, 2003.

WANG C, NGUYEN HN, MAGUIRE JL, PERRY DC: Role of intracellular calcium stores in cell death from oxygenglucose deprivation in a neuronal cell line. J Cereb Blood Flow Metab 22: 206-214, 2002.

YAMOAH EN, LUMPKIN EA, DUMONT RA, SMITH PJ, HUDSPETH AJ, GILLESPIE PG: Plasma membrane $\mathrm{Ca}^{2+}$-ATPase extrudes $\mathrm{Ca}^{2+}$ from hair cell stereocilia. $J$ Neurosci 18: 610-624, 1998.

YAO CJ, LIN CW, LIN-SHIAU SY: Roles of thapsigargin-sensitive $\mathrm{Ca}^{2+}$ stores in the survival of developing cultured neurons. J Neurochem 73: 457-465, 1999. 